\title{
Milestones in the History of Intelligence - Oradea as a Nodal Centre on the Regional Geopolitical Axis in the Security Equation
}

\author{
Phd Student Daniela Georgiana GOLEA \\ National Intelligence Academy "Mihai Viteazul"
}

\begin{abstract}
The East European region has always created a space of interaction between the great powers of the Eastern and Western Europe of the different epochs in European history. Not just a contact and an interaction region between Europe, Asia and the Middle East (Africa), but also a pivot of the European security environment, most often forming a real axis on which this scene of confrontation between powers can bend into one or the other part. We can say that the Eastern European region has formed hundreds of years ago (with the emergence of Ottoman power and its pressure on the Western powers, the emergence of the Tsarist and later Soviet power) a pivotal axis which determined the geopolitical configuration of the world and led successively to the advancement or decay of an empire or another. Indeed, the balance between Western powers and the Ottoman Empire, and later between the Austro-Hungarian Empire and the Eastern Powers, such as the Ottoman Empire and the Tsarist Empire, has been established for several hundred years right in this pivotal axis of Eastern Europe. For this reason, the political and military situation of the territories covered by the pivotal axis have always been a special one. This pivotal axis of Europe started from the Baltic Sea and was generally disposed over the continental strip where today are countries like Estonia, Latvia and Lithuania, a part of Poland (Pomerania and a part of Silesia), the Czech Republic, the western part of today Romania and a part of Serbia. This geographical positioning of the pivotal axis has led to a permanent political turmoil and change of borders in the mentioned regions. Referring exclusively to the manner in which this pivot axis intersected the current territory of Romania, we observe that in its passage from north to south it included Satu Mare, Oradea, Arad, Timişoara and Reşita. Oradea has always played an important role in Central-Eastern Europe, NATO recognizing the NATO HUMINT Centre of Excellence (HCOE) as a strategical organization with a remarkable contribution to the development of the Human Intelligence capability within the Alliance.
\end{abstract}

KEYWORDS: intelligence, regional geopolitical axis, geopolitical configuration, nodal point, Oradea, NATO HUMINT Centre of Excellence, European security environment

\section{INTRODUCTION}

From the research of the historical path of the European states it was observed that the balance of the regional security environment in the central and eastern area of Europe was most often determined by the dynamics of the relations (and, implicitly, the redesign of the borders) within a wide region of contact between the great Western and Eastern powers. This strip of surface of Central-Eastern Europe practically crosses Europe from north to south, forming a kind of vertical axis on which a large part of the dynamics of the regional security environment has developed.

We could say that this pivotal-axis has ensured the formation of a regional power balance over several hundred years, balancing the security environment. We can also observe from the historical analysis that the territories covered by this pivotal axis have for hundreds of years constituted a kind of exchange currency, an area of continuous re-establishment of the control and influence areas, where the interests of the great powers have been in constant and indirect interaction, which can only be highlighted by the political and territorial changes occurred in the pivotal space. So, for the countries covered by this axis, their borders were constantly fluid, the tracing of these borders being directly related to the great historical events. A portion of this centraleastern pivot-axis also crosses Romania's territory from north to south. This situation is not new at all, so it is possible to analyse the manner in which the region evolved over the last few hundred years.

The nodal point of the pivot axis that crossed (and still crosses) the territory of Romania, was at least for the last 2-3 hundred years, the city of Oradea. We will therefore pursue the historical evolution of this city by trying to assess its importance within the security environment and to anticipate the way in which Oradea could evolve from this perspective.

\section{THE ORADEA'S CITY HISTORY IN THE INTELLIGENCE ACTIVITY}


The archaeological discoveries have clearly confirmed the existence of an unexpectedly advanced culture and civilization in the Oradea region, from the Stone Age and the Bronze Age, respectively. Of course, we do not know exactly what extent and how important this locality was, in such a distant past. The fortress of Oradea was, however, mentioned in the documents of that time, in the 10th Century when reference was made to a fortified settlement whose location was situated at the sinking point of the tributary Pecce in the Crişul Repede River. In fact, in the 11th Century, the King of Hungary build a ward and a cathedral, respectively.

As well, starting with the 11th-12th Centuries, the city of Oradea become more important from a political and military point of view, being recorded by history as a place of pilgrimage for many of the kings of Hungary. What is important, however, is the role played by this fortress in the activities of storage, processing and selection of information in various fields, including the administrative and judicial ones. A particular importance is the systematization (in Oradea) of the information on land or other patrimony in almost the entire western region of Romania today.

The storage of important archives in Oradea attracted the time and importance of this city from the perspective of what we now call "the intelligence". The information gathered in the Oradea regional centre was not merely of a purely administrative or legal nature, but also of a political and military nature, including information from the Ottoman and Russian spheres. In 1658, the current name was recorded for the first time: Oradea, through the chronicler Miron Costin in „Letopisețul Țării Moldovei” (Costin, 2009), a work carefully studied later by the historian Nicolae Iorga and which was republished also in the contemporary period. The exact etymology of this name is still controversial, claimed by various authors either of Hungarian origin or a Turkish one, or even mixed.

A very important, yet little-known, aspect of Oradea is the manner in which it has been chosen the place of this city since ancient times and the way it was built vertically, simultaneously upwards but also downwards, by building important underground fortified structures. After a simple analysis of the geological structure of the Earth crust in the Oradea region, it is undeniable that the conditions for the formation of vast karst grids in the soil areas, some of which are confirmed, are fully met. The presence of surface waters (infiltrations from the Crişul Repede River) and especially the underground thermal waters, given that the surface layers are predominantly limestone, makes such layers surely penetrated (horizontally and vertically) by the action of water, giving rise to a vast network of channels. Besides, a similar phenomenon is currently encountered in the Budapest underground. In order to understand how this situation has been achieved (the development of Oradea in the beginning by underground construction and later on by surface construction) we will have to undertake a short geological survey (Săndulescu, 1984) of the Earth crust on which Oradea (Mutihac \& Ionesi, 1975) is located.

Only in this way will we understand the strategic importance of this fortress for hundreds of years, as well as the way in which even today Oradea presents a very big strategic potential. The geological structure of the Oradea (Vasilescu \& Nechiti, 1968) region is specific to the limestone plateau areas, plus the action of surface and underground waters (Tenu, 1981) - especially the thermal waters from the volcanic region of the Apuseni Mountains (Ianovici, Borcos \& Bleahu, 1976), which are responsible for the creation of many karst formations such as long tunnels, initially filled with rapid thermal groundwater. With the deposition of alluvial surface layers and because of the variable action of thermal waters (Vasilescu \& Nechiti, 1970) (which possess the characteristic high temperature and high pressure) some of these underground channels (those in the relative surface area) have dried up and thus become accessible for humans' use.

As in other cases, the city of Oradea constituted first of all a complex of constructions made by humans by arranging the karst structures near the surface of the soil, thus easily accessible. Subsequently, increasingly important constructions have been developed without diminishing the importance of the network made from underground tunnels and cavities. Perhaps the very existence of these catacombs made Oradea a favourite for many hundreds of years in terms of sheltering or hiding of various archives.

At present, from the data provided by the modern drillings for hydro-geological research in the Oradea area (Petrescu \& Nicorici, 1979), correlated with some similar results of the geological research carried out in the Oradea area, it has been proved that in the process of geological composition of the Earth crust on which it is located Oradea at present, participated the different layers belonging to geological periods such as Quaternary, Neogene, Paleogene, Cretaceous, Jurassic and Triassic, in the order of their depth. The basic structure is represented by metamorphic rocks. 


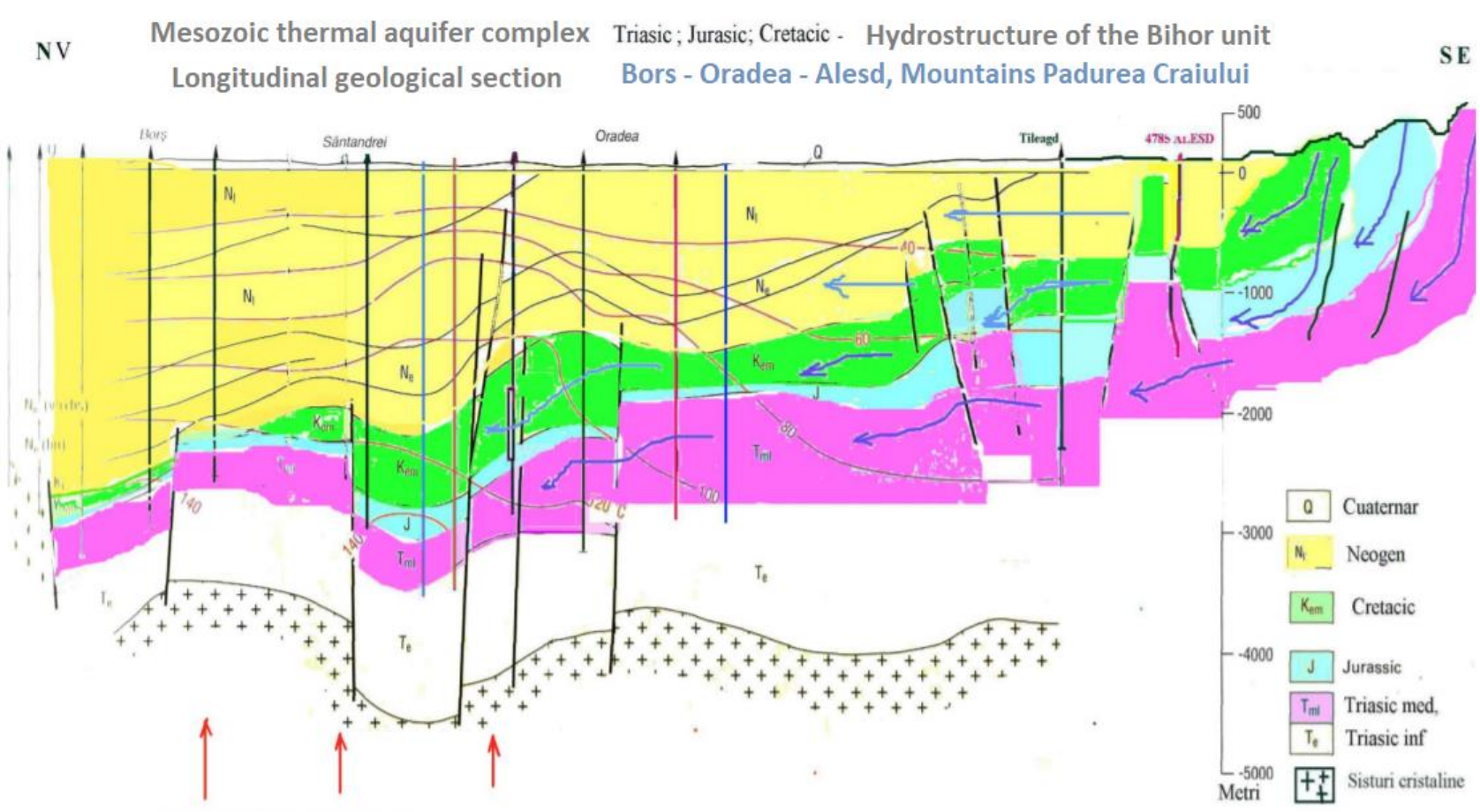

Figure 1 Longitudinal geological section - different layers belonging to geological periods

Hidro structure for Bihor area

(source https://centi.ro/info/workshop2012/calburean.pdf)

This allowed the Oradea underground to host a varied network of karst structures at greater or smaller depths, many of which found applications from the medieval period. The entire crystalline foundation of the Oradea area is also made up of a varied complex of mica-schist containing granites, tourmaline, along with black mica rock and a mixture of paragneiss with muscovite and biotite respectively.

The sedimentary formations belonging to the Unit of Bihor are disposed over these crystalline formations, easily penetrated by water infiltrations, and deposited over long periods along the Triassic, Jurassic and Cretaceous. Very important have been found to be the Triassic deposits, which are deposited transgressive directly above the crystalline base, consisting of various limestone. They are easily penetrated by water (Cohut , 1986) and lead to the formation of branched karst networks (Airinei , 1987). Besides, under Oradea the total thickness of these Triassic deposits varies from 500 to 1300 meters, with the possibility of the underground birth of various karst formations.

The Jurassic deposits described above contain a number of detrimental formations such as red clay shale, quartz sandstone or marble limestone. At the surface are the fine sandstone and the sedimentary limestone. These layers have a thickness ranging from 50 to 350 meters. In the Oradea area, there are sedimentary deposits in Cretaceous, also in the form of limestone coats, respectively grey ash. In the area of Oradea, these Cretaceous limestone constitute an important layer, which is crossed by various channels (flooded or not), forming a vast karst network (Airinei, 1981). With the withdrawal of water, such underground canals have been accessible to people since medieval times. Much more recent deposits are those in Miocene, which are generally made up of gneiss and sandy clays. Finally, the newest geological deposits are those of the Quaternary, in the form of the deposits formed by the alluvia of Crișul Repede River, in the form of sands and gravel.

As seen from the foregoing description, almost all of these layers (with the exception of the crystalline base) are sensitive to the action of waters, whether surface waters or underground thermal waters. The presence of this geological structure of the Oradea region actually explains from a scientific perspective, the manner in which the networks of underground canals and cavities appeared, these being later (especially during the medieval period in the 11th-12th centuries) used by those who built the fortress of Oradea. They were craftsmen from Italy, and they also formed an Italian mini-community in Oradea and in the fortress surroundings.

During the 15th Century, Oradea become an important regional centre of Renaissance culture. Noteworthy that Bishop Vitéz János established a large library in Oradea, along with important databases covering various fields of activity, also interested in the military field. After the Ottomans won the Battle of 
Mohács in 1526 in the struggle against the Magyars, the failure of the Hungarian kingdom led, among other things, to a complete reconsideration of the military importance of Oradea, becoming an important military centre within the autonomous kingdom of Transylvania. However, in 1660 Oradea was conquered by the Ottomans and later liberated from Ottoman domination in 1692 by the Austrian General Heissler Donath. With this victory, Oradea enters under Habsburg rule.

Thus, for more than a millennium, the city of Oradea (Nagyvárad in Hungarian or Grosswardein in German) was not only a regional (for the territory of Bihor County today) political-administrative centre but also an important military centre, having a special role in relating to collecting, selecting and storing information, in particular security information. Because of this, for long Oradea has sheltered important archives of political and military importance, not only administrative or cultural. Given that the city of Oradea is situated on the edge of Crişul Repede River, this route (partially navigable in the past with the help of rafts and light craft, especially in the route Oradea - Körösújfalu - Körösladány - Gyomaendrőd), made it also to have some importance in the regional business network scheme. Considered rightly to be the gateway to the west of Romania, Oradea has long been the communications hub of the Western part of Transylvania and Hungary (Partium) during the Hungarian domination.

Beginning with the XVIII ${ }^{\text {th }}$ Century in Oradea were built several large-scale buildings, confirming once more the importance of the fortress. In the same Century, Oradea also became the centre of Romanian political and cultural movements for the national rights. During the revolution of 1848 , Oradea become the regional centre of the Hungarian bourgeois-democratic revolution, among other things being used for the storage of large quantities of weapons and ammunition. But also, by means of production of armaments.

The role of Oradea was also important in terms of what we call today "intelligence activity", especially during the existence of the Austro-Hungarian Empire. Moreover, during the Austro-Hungarian Empire (between 1867 and 1918) Oradea fortress became an important cultural centre of the entire Empire, but also a regional centre of economic development, we refer especially to the industrial development and the beginning of the systematic exploitation of oil and natural gas in the territory of today's Romania.

Let us note that between 1092 and 1660, the Oradea fortress was under Transylvanian order and administration (Hungarian, in fact, with short periods of administration in other hands), between 1660 and 1692 it was in order and Ottoman administration and in the modern period between 1692 and 1918 it was under Habsburg and Austro-Hungarian administration (after 1867). Also note that over the catacombs made or adapted since the medieval period, the Oradea fortress has also Roman, Gothic and Renaissance-Baroque architectural works. In the XVI ${ }^{\text {th }}$ and XVII ${ }^{\text {th }}$ Centuries, the general appearance of the fortress became as a Italian bastion, being surrounded by a series of small settlements populated by Italian craftsmen.

As a geographical position, Oradea is situated on the outskirts of Bihor County, with a very varied relief, of which $44 \%$ of its area is occupied by the lowland, $31.6 \%$ by the hills and $24 \%$ by the mountains, the maximum altitude (1849 meters) being touched by Curcubăta Peak (Vlădeasa Mountains). The mountain ranges in Bihor county include the largest volumes of karst relief in Romania, making this county the most important region of Romania in terms of resistance or guerrilla warfare, because it allows the simple masking of a very large number of people and even heavy fighting techniques in large quantities. In the formation of karst structures such as valleys, gorges and caves an important role was played by the action of geothermal waters.

\subsection{ORADEA ON THE PIVOT AXIS OF EUROPE}

As pointed out in the previous paragraph, Oradea constituted a regional node centre at the East European interference between the interests and actions of the great powers of various epochs. Therefore, the city of Oradea has been an important centre for obtaining, storing, processing in various forms and disseminating data and information of a diverse nature (cultural, scientific, political, military) from the medieval period. An important aspect was the formation (over the centuries) of a pivot-axis that generally crossed Europe from north to south in its eastern region. The surface covered by this pivotal-axis of the regional power balance from the very beginning constituted a politically and military volatile region in which the interests of the great powers interpenetrated and thus formed an unstable security environment, in a constant motion.

Therefore, the region of Oradea was subjected to mixed influences, in which the Turks, the Austrians (Habsburgs), the Hungarians, the Romanians and the Italians have a hard word to say. These influences covered areas such as politics and administration, military situation, cultural and industrial development, etc. Interesting (and specific to pivotal areas) is that often these influences acted concurrently, without interfering with each other. Interestingly, it is worth mentioning that the Soviets (after 1944) also attached a special importance to the Bihor area, but for purely economic reasons, in the Băiţa area, where uranium ore of superior quality was found. 


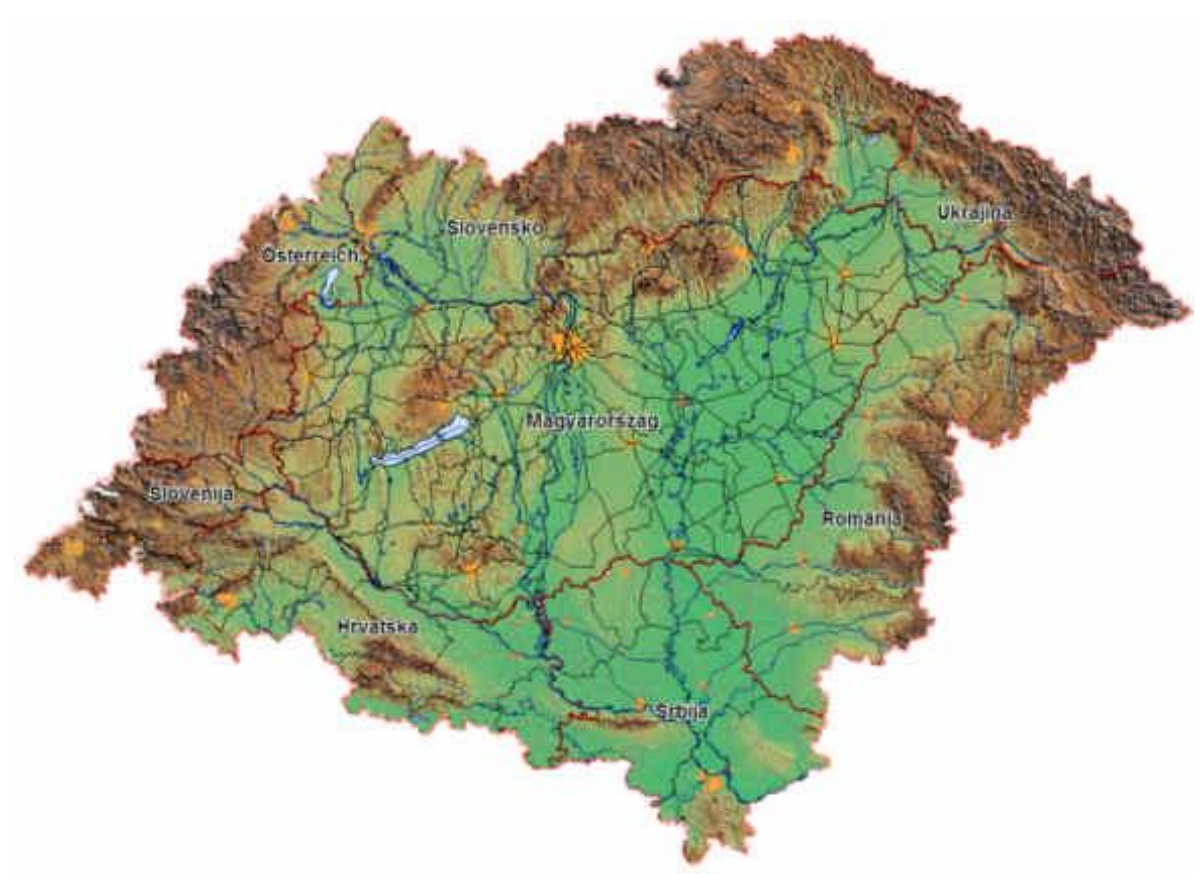

Figure 2 The economic development zone proposed by Hungarians in terms of railways (according to http://vasutallomasok.hu/terklist.php )

It is noted the inclusion of a strip from the western part of Romania. Naturally, this should mean nothing but an innocent regional development plan for the main transport networks, if the Romanian region does not really overlap perfectly with the Romanian territory where is the pivotal-axis of the European balance of power.

During the Habsburg and Austro-Hungarian periods the intelligence services of these powers did not carry out obviously aggressive actions, after the Treaty of Versailles and the loss of Transylvania by the Hungarians, the tensions in the region increased and the intelligence activity intensified. At the beginning of 1938, the Hungarian authorities stepped up their subversive actions, trying to organize groups for espionage and research-diversion activities in Transylvania, including sabotage and terrorist attacks. To these activities were also attracted people from the Hungarian minority located in the territory of Transylvania.

The aim was that such formations would become active in the hypothesis of carrying out Hungarian military offensive operations against Romania. Practically, this was an action of the Hungarian intelligence services, and their bases of action focused on Oradea (Calafeteanu, 1995). Thus, before the outbreak of the Second World War, Oradea was able to play an increasingly important role in the Intelligence Action Scheme, being considered by some sources (National Archives) to be a real turntable of the Hungarian secret services.

According to the information available to us (National Archives, quoted source) in 1938-1939, the major state (command) of all Hungarian terrorist nuclei in Transylvania was established in Oradea., where was coordinated the activities of diversionary groups from Alba Iulia, Timisoara, Brasov, Sibiu, Cluj and Huedin.

Interestingly, since 1993, the Russian intelligence forces on the Romanian territory restricted their activity focusing mainly on cities such as Tg.Mures, Sf. Gheorghe and Covasna. With the outbreak of the Crimean crisis in the years 2013-2014, the Hungarians demonstrated that they are in fact hostile to NATO and also their public sympathy for the Russian Federation, hoping for the help of this great regional power in the Hungarian claims on Transylvania.

Another interesting aspect is the one related to the distribution of Romania's first three major missile divisions in 1967: Lugoj, Oradea and Corbu, in Constanța County. Although NATO forces could not attack at that time through the Black Sea (Turkey), the Romanians' defence effort was practically the border with Hungary.

Remarkably, during the December 1989 events in Oradea, no one died, with a perfectly organized passage of power into the hands of the new political forces, while in the neighbouring large cities bloody events took place. Currently, Oradea is growing in importance on the regional map of intelligence activities, because in this place are perhaps concentrate (already traditionally) the command centres of Hungarian intelligence in Romania, and with them there is also a growing Russian presence. Moreover, the Western powers represented 
here in a very visible way through NATO's regional command, only increases the interest of other intelligence services for Oradea.

\subsection{ORADEA IN TERMS OF STRATEGIC SECURITY ASPECTS}

At the moment, Oradea is an increasingly interesting place, and it is from several perspectives that concern the security field: from the perspective of the presence here of regional command and training centres both NATO forces and intelligence organizations (Constantinescu, 2015); in the perspective of the presence of very large quantities of rare natural resources in the basement of Bihor County. NATO recognizing the NATO HUMINT Centre of Excellence (HCOE) as a strategical organization in Central-Eastern Europe with a remarkable contribution to the development of the Human Intelligence capability within the Alliance.

Of course, we cannot clearly state that such forces exist at present on the Romanian territory, but it is enough to look back in history to find that these forces were practically permanent after the conclusion of the Treaty of Versailles (1919) to wait for the moment to be activated. Such a moment was December 1989 and then, March 1990, and it was already clear at that time that the events did not happen spontaneously nor thanks to the exclusive action of some internal factors.

Judging from the perspective of the presence in Oradea of some important centres for the leadership and/or training of NATO personnel, we can see that the geographical location of these headquarters is very well chosen, Oradea being relatively protected (by its geographic layout and by the manner in which Romania's relief shields against possible assaults) in front of possible attacks coming from the East. Moreover, the regional communication routes (by air and land) allows for a large flow of vehicles from different categories, if necessary, in a relatively short time. By comparison, although Timişoara is relatively similarly located in the western border region, it is too far from what NATO considers as a safe access routes.

From the perspective of the presence in Bihor County of some qualitative and quantitative natural resources, we can say that Oradea is also a good centre for the coordination of possible economic exploitation activities, especially if we refer to natural resources with strategic impact. According to the latest official evaluations made by the National Agency of Mineral Resources (ANRM), Bihor County would currently have the most varied range of underground and surface natural resources. According to the agreements made by Romania with various foreign partners, ANRM issued specially for Bihor County a series of licenses and permits aimed to exploit not less than 22 different types of natural resources, including: poly-metallic and goldsilver ore, rare bismuth ores, tungsten and molybdenum, geothermal waters and therapeutic mineral waters, limestone ores of various types, clay of various types, sandstone and sand, marble, marl.

It is known today that Bihor County has also resources still untapped of crude oil and natural gas, including the much controversial shale gas. A large brucite deposit is located at Budureasa and it is currently under consideration. Bihor County has also a vast network of caves due to the underground action of geothermal waters, which makes the whole area very interesting from a military point of view, given the capacity for hiding the combat personnel and the combat technique. The mechanism of formation of these karst structures is similar to that described earlier in the study of the underground of Oradea. The karstic formations also usually indicate the presence of rare, particularly valuable deposits such as gold, silver, molybdenum and bismuth alloys, tungsten, copper, zinc, lead and others such as bauxite or lignite. It is known the existence of large lignite deposits at Barcău, Borod or Popești Suplacul, bauxite deposits in Pădurea Craiului Mountains, the Suplacu de Barcău oil basins, the bituminous shale layers at Derna and Tătăruş.

Although at first sight it seems to be unrelated to the military aspect, the existence of natural resources is in fact very important from a military perspective as it ensures the permanent supply of the war machine, and the presence of numerous natural underground cavities makes easy the storage of strategic resource stocks, sheltering from enemy attacks or its trying to stop the ore mining and the processing operations.

\section{CONCLUSIONS}

Nowadays Bihor County concentrates a series of strategic interest elements, all of which bring the capital of the county, Oradea, to an increasingly important position:

- the location of Bihor and Oradea in a communication node, requires the development of Oradea airport, in order to increase the transit flow and the capacity to receive as many heavy aircraft as possible; 
- starting with 2018, Oradea, is considered the second "smart city" in Romania, due to the smart projects and digitalization of local services for the citizens (smart parking, internet free, e-government) - according to the Forbes magazine and the "Radiography Smart City Romania"- Report.

- the existence within the county of an impressive number of natural resources, some of them extremely rare and in considerable quantities; the centre of command of regional economic activities would gradually become the city of Oradea;

- the varied relief of Bihor County makes the region very interesting from a military point of view, allowing both the effective protection in the event of an armed aggression and the development of training bases with diverse activities (on field, mountain) but located practically in the same county;

- the very varied karst structures in the underground of this county, including the underground of Oradea, make these regions very important for the special military applications, both during peace period and especially in case of an armed conflict;

- traditionally (for several hundred years) Oradea has been a regional centre for intelligence coordination or command, here acting both Hungarians, Austrians, Turks, Romanians, Russians, according to the dynamics of the security environment and the balance of power in this part of Europe;

- Oradea occupies the central place (reported exclusively on the territory of Romania) within the pivotaxis on which the regional mechanism for balance of power in Eastern Europe is mounted; this pivot-axis crosses the western area of Romania from north to south and the most important security elements are concentrated in the city of Bihor.

\section{References}

Airinei, Ș., (1987), Geotermia cu aplicații la teritoriul României, Editura Ştiinţifică şi Enciclopedică, Bucureşti.

Airinei, Ș., (1981), Potențialul geotermic al subsolului României, Editura Științifică și Enciclopedică, București.

Arhivele Naţionale Centrale, Fond Ministerul Propagandei Naţionale, Colecţia de Studii şi Documentare, dosarul 230, pp. 113-119.

Calafeteanu, I., (1995), Revizionismul ungar şi România, Editura Enciclopedică, Bucureşti, p. 16-50.

Cohuţ, I., (1986), Sistemul hidrogeotermal Oradea-Felix, în „Anuar Crisia”, nr.16, pp. 616-628.

Constantinescu, M., Popa, B.M., (2015) Defence resources management in the 21st century, The 10th scientific conference with international attendance organized by the regional department of defence resources management studies, National Defence University,,Carol I” Publishing House, Brasov

Costin, M., (2009), Letopiseţul Ţării Moldovei, Editura Herra, Pitești.

Golea, D.G., Petcu, I., Tirla, A.M., (2019) O nouă paradigmă: resursa forestieră din perspectiva securităţii energetice, Romanian Journal of Information Technology and Automatic Control, vol. 29(4), pp. 63-74Mutihac, V., Ionesi, L., (1975), Geologia României, Editura Tehnică, București.

Ianovici, V., Borcoş, M., Bleahu, M., Patrulius, D., Lupu, M., Dimitrescu, R., Savu, H., (1976), Geologia Munţilor Apuseni, Editura Academiei Republicii Socialiste Românie, Bucureşti.

Petrescu, I., Nicorici, E., (1979), Biostratigrafia depozitelor pliocene din forajele de la Roşiori-Oradea şi Voivozi, studiu aflat la Muzeul Țării Crişurilor, Oradea.

Săndulescu, M., (1984), Geotectonica României, Editura Tehnică, Bucureşti.

Țenu, A., (1981), Zăcămintele de ape hipertermale din nord-vestul României, Editura Academiei Republicii Socialiste România, Bucureşti.

Vasilescu, G., Nechiti, G., (1970), Cercetări hidrogeologice în zona staţiunilor balneare Felix și 1 Mai din judeţul Bihor, în „Studii tehnice și economice”, București, p.115-133

Vasilescu, G., Nechiti, G., (1968), Contribuții la cunoaşterea geologiei şi hidrogeologiei zonei orașului Oradea, Buletinul Societății de Știinte Geologice din România, vol.X, București, p. 291-307.

Vevera, A.V. (2014), Ameninţări cibernetice globale şi naţionale, Romanian Journal of Information Technology and Automatic Control, vol 24, Nr . 3 